\title{
Pengaruh Karakter Eksekutif, Ukuran Perusahaan, Kualitas Audit, dan Komite Audit Terhadap Tax Avoidance
}

\author{
Retno Pujilestari \\ Mustika Winedar
}

Fakultas Ekonomi dan Bisnis Universitas Dr. Soetomo Surabaya

\begin{abstract}
This study aims to examine the effect of Executive Character, Company Size, Audit Quality, and Audit Committee on Tax Avoidance. Executive Character is measured by calculating company risk, Company Size is determined based on company size, Audit Quality is stated based on who KAP audits the company, and Audit Committee is determined based on the number of Audit Committees in the company. While Tax Avoidance is measured by CETR. By taking samples of mining companies that are active and listed on the Indonesia Stock Exchange for the period of 2012 to 2016 selected by purposive sampling technique, the research data collected through documentation techniques are then analyzed by multiple linear regression and the results show that Executive Character, Company Size, Quality Audit, and the Audit Committee simultaneously have a significant effect on Tax Avoidance. But partially only Audit Quality has an effect on Tax Avoidance.
\end{abstract}

Kata Kunci : Karakter Eksekutif, Ukuran Perusahaan, Kualitas Audit, Tax Avoidance

\section{PENDAHULUAN}

Sebagai salah satu sumber penerimaan Negara, realisasi penerimaan Negara dari sektor pajak sejak tahun 2008 tidak pernah mencapai target yang telah ditetapkan. (Kusuma. 2017). Penyebab tidak tercapainya target penerimaan pajak antara lain disebabkan oleh melambatnya pertumbuhan ekonomi pada sektor industri pengolahan dan sektor pertambangan. (CNN Indonesia. 2015). Selain itu disebabkan juga oleh optimisme pemerintah yang terlalu tinggi dalam menetapkan target penerimaan pajak. (Merdeka.Com. 2017). Penerimaan pajak yang tidak mencapai target menunjukkan upaya pemerintah dalam menaikkan penerimaan pajak masih belum optimal. 
Kendala yang dihadapi oleh pemerintah dalam meningkatkan penerimaan pajak negara salah satunya adalah tindakan penghindaran pajak (tax avoidance) yang dilakukan oleh Wajib Pajak.

Fenomena maraknya praktek Tax Avoidanece di Indonesia dapat dilihat antara lain dari Laporan yang dirilis Kemetrian Keuangan Republik Indonesia pada tahun 2016 yang melaporkan terdapat 2000 perusahaan Penanaman Modal Asing (PMA) di Indonesia yang tidak membayar pajak selama 10 tahun terakhir dengan alasan perusahaan-perusahaan tersebut mengalami kerugian. Sedangkan menurut perhitungan dan pemeriksaan yang dilakukan DJP, perusahaan perusahaan tersebut seharusnya membayar pajak rata-rata Rp 25 Milyar per tahun. Berdasar fakta tersebut diindikasikan bahwa perusahaan perusahaan PMA tersebut melakukan penggelapan pajak.

Pada 2017 peneliti kebijakan ekonomi dari Publish What You Pay (PWYP) Indonesia melaporkan bahwa pada sektor pertambangan yang meliputi migas, mineral, dan batubara/bahan galian, persentase kenaikan aliran uang ilegal ke Luar Negeri pada kurun waktu 2013-2014 mencapai $102,42 \%$, hal ini disebabkan oleh banyaknya transaksi perdagangan dengan faktur palsu sehingga ekspor komoditas pertambangan hasil aktifitas ilegal tersebut tidak tercatat. Nilai realisasi penerimaan pajak sektor pertambangan hanya mencapai 96,6 triliun, jika dibandingkan dengan Product Domestic Bruto (PDB) yang mencapai 1.026 Triliun, rasio penerimaan pajak dari sektor pertambangan hanya 9,4\%. Kecilnya persentase tax ratio ini mengindikasikan terjadinya tax avoidance yang melibatkan perusahaan pertambangan di Indonesia dan merugikan keuangan Negara.

Beberapa penelitian terdahulu menuliskan bahwa karakter eksekutif, ukuran perusahaan, kualitas audit dan komite audit berpengaruh terhadap praktek penghindaran pajak oleh perusahaan.

Peran pimpinan perusahaan sangat menentukan dalam aktivitas penghindaran pajak yang dilakukan perusahaan. Karakter pimpinan perusahaan mempengaruhi kebijakan yang ia ambil, seorang pimpinan dengan karakter risk taker akan cenderung lebih berani mengambil keputusan yang diikuti resiko yang tinggi, Sedangkan pimpinan yang memiliki karakter risk averse cenderung menolak resiko, Dari 
penelitian yang dilakukan Dyreng et al. (2010) serta Budiman dan Setiyono (2013) menyatakan bahwa karakter eksekutif berpengaruh terhadap perilaku penghindaran pajak yang dilakukan oleh perusahaan.

Ukuran perusahaan adalah pengklasifikasian perusahaan ke dalam kategori besar hingga kecil berdasar nilai total aset (Hormati, 2009). Semakin besar ukuran perusahaan maka transaksi yang dilakukan semakin kompleks yang memungkinkan perusahaan untuk memanfaatkan celah-celah yang ada untuk melakukan tindakan tax avoidance dari setiap transaksi. Hasil penelitian yang dilakukan Surbakti (2012) menunjukkan bahwa ukuran perusahaan berpengaruh positif terhadap penghindaran pajak.

Faktor lain yang dapat mempengaruhi suatu perusahaan untuk melakukan kewajiban pajaknya adalah corporate governance. Proksi dari corporate governance yang digunakan dalam penelitian ini adalah kualitas audit dan komite audit.

Salah satu karakteristik dari corporate governance adalah kualitas audit, tax avoidance juga dipengaruhi oleh kualitas audit. Auditor dengan reputasi yang baik akan memiliki dorongan untuk menyediakan kualitas audit yang tinggi secara terus menerus untuk mencegah hal-hal yang nantinya dapat merusak reputasi mereka. Hasil penelitian oleh Annisa dan Kurniasih (2012) menunjukkan bahwa reputasi auditor berpengaruh signifikan terhadap tax avoidance, sedangkan hasil dari penelitian Kanagaretnam, dkk (2015) dan Maharani dan Suardana (2014) menunjukkan bahwa kualitas audit berpengaruh negativ terhadap tax avoidance.

Selain kualitas audit, komite audit juga merupakan bagian dari karakteristik corporate governance. Komite audit dibentuk oleh Dewan Komisaris dalam rangka membantu tugas dan fungsinya. Hasil penelitian dari Annisa dan Kurniasih (2012) dan Adeyani (2013) menunjukkan bahwa komite audit berpengaruh signifikan terhadap tax avoidance, sedangkan menurut Maharani dan Suardana (2016) komite audit berpengaruh negative terhadap tax avoidance. Namun penelitian yang dilakukan oleh Kurniasih dan Sari menunjukkan bahwa komite audit tidak memiliki pengaruh yang signifikan terhadap tax avoidance.

Ketidak konsistensian dari hasil penelitian yang dilakukan peneliti sebelumnya mendorong peneliti untuk melakukan pengujian kembali terhadap 
variabel-variabel tersebut. Variabel yang ingin dikaji ulang oleh peneliti terkait tax avoidance adalah karakter eksekutif, ukuran perusahaan, kualitas audit, dan komite audit pada perusahaan pertambangan. Alasan utama yang menjadikan perusahaan pertambangan sebagai objek oleh peneliti karena pada sektor tersebut menjadi bahan perbincangan terkait kepatuhan wajib pajaknya yang tergolong menurun dari waktu ke waktu. Perusahaan sektor tambang dinilai sebagai sektor yang paling rentan dalam melakukan penghindaran pajak yang menyebabkan kerugian negara yang tidak sedikit (Prasetyo, 2017).

Permasalahan yang hendak dijawab oleh peneliti yaitu apakah karakter eksekutif, ukuran perusahaan, kualitas audit, dan komite audit berpengaruh signifikan terhadap tax avoidance pada perusahaan sektor pertambangan yang terdaftar di Bursa Efek Indonesia 2013-2017.

\section{KAJIAN TEORI DAN PENGEMBANGAN HIPOTESIS}

\section{Teori Agensi}

Tujuan normative pengambilan keputusan keuangan yang menyatakan bahwa keputusan diambil untuk memaksimumkan kemakmuran pemilik perusahaan, hanya benar apabila pengambil keputusan keuangan (agent) memang mengambil keputusan dengan maksud untuk kepentingan para pemilik perusahaan (Husnan dan Pudjiastuti, 2012).

Principal mempercayakan pengambilan keputusan kepada agent, yang berarti kedua belah pihak telah mempunyai kesepakatan bersama atas tanggung jawab yang diserahkan kepada pihak agent. Akan tetapi timbul asymmetry information, yaitu agent agent yang mempunyai informasi lebih banyak dibandingkan principal yang hanya mengetahui sebagian yang dilaporkan saja. Ketidakseimbangan informasi yang didapatkan ini dikarenakan agent mempunyai informasi lebih banyak cenderung melakukan tindakan yang sesuai keinginan untuk memaksimumkan utilitinya, sehingga terkadang menimbulkan kebijakan-kebijakan tertentu yang hanya diketahui oleh pihak agent saja tanpa sepengetahuan dari pihak principal.

\section{Tax Avoidance}

$\begin{array}{rrr}\text { Pokok } & \text { utama } & \text { dalam tax } \\ \text { avoidance } & \text { adalah } & \text { mengurangi } \\ \text { kewajiban } & \text { pajak } & \text { dengan }\end{array}$
menghilangkan konsekuensi ekonomi 
yang ditujukan kepada setiap individu yang telah memenuhi syarat sebagai wajib pajak. Sifat tax avoidance yang sah menurut hukum membuat perusahaan tidak dapat dijatuhi sanksi langsung, sanksi dapat diberikan apabila undang-undang telah secara jelas mengatur batasan-batasan dalam tax avoidance (Prebble dan Prebble, 2010).

\section{Hipotesis}

$\mathrm{H}_{1}$ : Karakter Eksekutif, Ukuran perusahaan, Kualitas Audit dan Komite Audit secara simultan berpengaruh terhadap tax avoidance.

$\mathrm{H}_{2}$ :Karakter Eksekutif, Ukuran Perusahaan, Kualitas Audit dan Komite Audit secara parsial berpengaruh terhadap tax avoidance.

\section{Kerangka Konseptual}

Gambar 1. Model yang dihipotesiskan

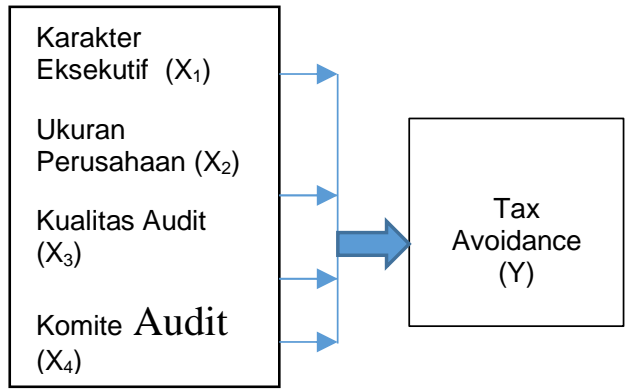

$\longrightarrow=$ arah hubungan secara

partial $\square=$ arah hubungan secara simultan

\section{METODOLOGI PENELITIAN}

\section{Populasi dan Sampel}

Populasi dari penelitian ini adalah seluruh perusahaan pertambangan yang terdaftar di Bursa Efek Indonesia. Sampel pada penelitian ini adalah perusahaan pertambangan yang masih aktif dan terdaftar di Bursa Efek Indonesia periode 2012-2016 adalah 200 perusahaan pertambangan. Teknik pengambilan sampel pada penelitian ini adalah menggunakan metode purposive sampling, yaitu dengan mengambil sampel dari populasi derdasarkan criteria perusahaan yang bergerak dibidang pertambangan yang masih aktif dan terdaftar di Bursa Efek Indonesia periode 2013-2017, memiliki data laporan tahunan dan laporan keuangan yang lengkap, menggunakan nilai mata uang rupiah dan dolar, serta memiliki keuntungan atau laba yang bernilai positif. Dan menggunakan tahun buku pada 31 Desember pada laporan keuangan tahunan.

Setelah dilakukannya purposive sampling maka perusahaan pertambangan periode 2012-2016 yang memenuhi kriteria adalah 85 perusahaan. 


\section{Identifikasi Variabel}

i. Variabel dependen pada penelitian ini adalah Tax Avoidance.

ii. Variabel independen pada penelitian ini adalah Karakter Eksekutif, Ukuran Perusahaan, Kualitas Audit, dan Komite Audit

\section{Pengukuran Variabel}

Pengukuran variabel tax avoidance dalam penelitian ini mengikuti Dyreng et al. (2008) dan Budiman (2012) menggunakan CETR (Cash Effective Tax Rate) dengan membagi cash tax paid dengan pretax income. Dyreng (2008) menyatakan tidak seperti ETR (Effective Tax Rate), CETR tidak terpengaruh oleh perubahan estimasi seperti maluation allowance dan tax cushion. Nilai cash tax paid dapat dilihat pada pelaporan arus kas dari aktivitas operasi. Semakin besar nilai CETR mengidentifikasikan perusahaan tidak melakukan tax avoidance. Metode pengukuran CETR adalah sebagai berikut :

\section{CETR = Pajak yang dibayarkan perusahaan}

Laba sebelum pajak

Karakter eksekutif dapat diukur menggunakan rumus standar deviasi sebagai berikut :

$$
\frac{\left.\sqrt{\sum_{T-1}^{T}\left(E-1 / T \sum_{T-1}^{T} E\right.}\right)^{2}}{\mathrm{~T}-1}
$$

Keterangan :

$\mathrm{E}=$ EBTIDA atau Total Asset

$\mathrm{T}=$ Total Sampel

Karakter eksekutif jika memiliki nilai resiko yang tinggi menunjukkan bahwa pimpinan perusahaan cenderung bersifat risk taker, sedangkan yang memiliki nilai resiko rendah menunjukkan piimpinan perusahaan menghindari kesempatan yang dapat menimbulkan resiko yang bersifat risk averse.

Ukuran Perusahaan dapat dihitung dengan cara mentransformasikan kedalam logaritma natural menurut Ghozali (2016). Sehingga dapat di rumuskan sebagai berikut: $S I Z E=L n$ Total Asset

Komite audit dapat dihitung mengunakan rumus seperti berikut ini : Komite Audit $=\sum$ Anggota Komite Audit perusahaan

\section{Metode Analisis}

\section{Analisis Statistik deskriptif, yaitu} teknik analisis yang memberikan penjelasan mengenai informasi data yang dimiliki namun tidak untuk menguji hipotesis penelitian yang dirumuskan. Analisis statistik deskriptif memiliki tujuan untuk 
menganalisis data dan menghitung berbagai karakteristik data yang diteliti. Statistic deskriptif menunjukkan jumlah sampel, nilai minimum, nilai maksimum, nilai ratarata dan standar deviasi (Ghozali, 2016).

\section{Uji Asumsi Klasik}

Uji normalitas menguji data sampel normal atau tidak dengan cara menditeksi dengan uji statistic dengan "table Kolmogorov Smirnov". Uji statistic dengan Kolmogorov Smirnov Z (1-Sampel K-S), dasar pengambilan keputusan dengan kriteria pengujian $\alpha$ $=0,05$ dimana :

1. Data residual berdistribusi normal, apabila angka signifikasi $\geq 0,05$.

2. Data residual berdistribusi tidak normal, apabila angka signifikasi $<0,05$.

Uji Autokorelasi, untuk menguji apakah dalam model regresi linier terdapat korelasi antara kesalahan pengganggu pada periode $\mathrm{t}$ dengan kesalahan pengganggu pada periode $t_{1}$ (sebelumnya). menggunakan Run Test. Uji Run Test dilihat pada nilai signifikan yang $>0.05$ Apabila probabilitas signifikansinya $>0.05$ maka dapat disimpulkan bahwa residual random atau tidak terjadi autokorelasi dalam model regresi.

Uji multikolinieritas menguji apakah model regresi ditemukan adanya korelasi antar variabel bebas (independen).yang dapat dilihat dari Variance Inflation Factor (VIF) dan tolerance value dari masing-masing variabel bebas terhadap variabel terikat yang di uji. Batas nilai VIF adalah 10 dengan tolerance value 0,1 . Apabila nilai VIF lebih dari 10 maka menunjukkan adanya gejala multikolinearitas. Sebaliknya jika nilai VIF kurang dari 10 dapat dinyatakan tidak terjadi multikolinearitas.

Uji heteroskedatisitas menguji ada tidaknya ketidaksamaan varians dalam model regresi dari pengamatan ke pengamatan lainnya. Dalam penelitian ini menggunakan uji glejser yaitu meregresi nilai absolute residual terhadap variabel dependen (Ghozali 2016: 142). Jika variabel independen signifikan secara statistic mempengaruhi variabel dependen, maka ada indikasi terjadi heteroskedastisitas.

\section{Uji Hipotesis}

Uji F digunakan untuk mengetahui apakah variabel independen karakter eksekutif, ukuran perusahaan, kualitas audit dan komite 
audit mempunyai pengaruh negative terhadap variabel dependen tax avoidance. Untuk menilai kelayakan model, Uji F dilakukan dengan melihat nilai $\mathrm{F}$ dan signifikasi. Semakin rendah nilai signifikasi menunjukkan bahwa model yang dibangun memiliki kemungkinan kesalahan yang lebih rendah. Apabila $($ Sig. $<0,05)$ maka dapat disimpulkan bahwa model layak dan baik untuk digunakan.

Koefisian determinasi $\left(\mathrm{R}_{2}\right)$ pada intinya mengukur seberapa jauh kemampuan model menerangkan variasi variabel dependen (Ghozali, 2011). Nilai adjusted $\mathbf{R}_{2}$ yang mendekati satu berarti kemampuan variabel-variabel independen memberikan hampir semua informasi yang dibutuhkan untuk mendeteksi variasi variabel dependen. Uji koefisien Determinasi $\left(\mathrm{R}_{2}\right)$ digunakan untuk mengukur sejauh mana kemampuan model dalam menerangkan variasi variabel dependen. Nilai $R_{2}$ berada diantara 0 dan 1.

Uji statistik $t$ menunjukkan seberapa jauh pengaruh variabel independen secara individual terhadap variabel dependen.

\section{Analisis Regresi Linier Berganda}

Teknik analisis data yang digunakan pada penelitian ini adalah menggunakan analisis linear berganda, karena pada penelitian ini menggunakan variabel independen lebih dari satu. Analisis linear berganda digunakan untuk mengetahui besarnya pengaruh dari variabel independen : karakter eksekutif, ukuran perusahaan, kualitas audit, dan komite audit dengan variabel dependen : tax avoidance. Persamaan pada penelitian ini adalah sebagai berikut :

$$
\begin{gathered}
\text { TA }=\alpha+\beta_{1} \text { RISK }+\beta_{2} \text { SIZE }+ \\
\beta_{3} \mathrm{KLT}+\beta_{4} \mathrm{KMT}+\mathrm{e}
\end{gathered}
$$

Keterangan:

$\alpha$ : Konstanta Persamaan Regresi

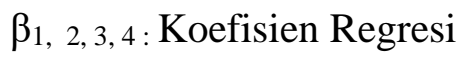

TA : Tax Avoidance ( dihitung menggunakan CETR )

RISK : Karakter Eksekutif

SIZE : Ukuran Perusahaan

KLT : Kualitas Audit

KMT : Komite Audit

e : error term

\section{HASIL DAN PEMBAHASAN}

Variabel yang digunakan dalam penelitian ini adalah Tax Avoidance sebagai variadel dependen dan Karakter Eksekutif, Ukuran Perusahaan, Kualitas Audit, serta 
Komite Audit sebagai variabel independen.

Tax Avoidance dapat diukur menggunakan CETR (Cash Effective Tax Ride) Yang dikemukakan oleh Rodriguez dan Arias (2012) dalam Ida Ayu dan Ketut Alit (2016). Dimana CETR $=\frac{\text { Pajak yang dibayar perusahaan }}{\text { Laba Sebelum Pajak }}$ Semakin besar nilai CETR maka semakin rendah tingkat penghindaran pajak suatu perusahaan. Variabel diuji untuk menghasilkan nilai maksimum, minimum, rata-rata (mean), dan standar deviasi.

Selama kurun waktu 2012-2016 posisi CETR minimum ditempati oleh PT. Bara Jaya Internasional Tbk. (ATPK) dengan nilai 0,0142 atau 1,412 persen. PT. Bara Jaya Internasional Tbk. (ATPK) menempati posisi ini pada tahun 2014, hal ini menunjukkan bahwa perusahaan tersebut cenderung melakukan Tax Avoidance karena hasil perhitungan CETR-nya sangat kecil. Sedangkan dalam kurun waktu 20122016 posisi CETR maksimum ditempati oleh PT. Timah (Persero) Tbk. (TINS) dengan nilai 0,9027 atau sebesar 90,27 persen. PT. Timah (Persero) Tbk. (TINS) menempati posisi ini pada tahun 2012. Hal ini menunjukkan bahwa perusahaan tersebut cenderung tidak melakukan
Tax Avoidance karena hasil perhitungan CETR-nya besar. Kemudian untuk nilai rata-rata (mean) sebesar 0.398950 dan nilai standar deviasi sebesar 0,2009166. dari tabel diatas dapat dinyatakan bahwa nilai standar deviasi lebih kecil dibandingkan nilai rata-rata (mean) yang berarti bahwa tingkat sebaran data tax avoidance terbilang kecil atau bersifat homogen, yang berarti bahwa perusahaan pertambangan selama periode 2012-2016 memiliki nilai CETR yang rendah yang mengidentifikasikan perusahaan tidak melakukan tax avoidance.

Karakter eksekutif dapat diukur menggunakan rumus standar deviasi seperti dibawah ini :

$$
\frac{\sqrt{\sum_{T-1}^{T}\left(E-1 / T \sum_{T-1}^{T} E\right)^{2}}}{\mathrm{~T}-1}
$$

Keterangan :

$\mathrm{E}=$ EBTIDA atau Total Asset

$\mathrm{T}=$ Total Sampel

Karakter eksekutif jika memiliki nilai resiko yang tinggi menunjukkan bahwa pimpinan perusahaan cenderung bersifat risk taker, sedangkan yang memiliki nilai resiko rendah menunjukkan piimpinan perusahaan menghindari kesempatan yang dapat menimbulkan resiko yang bersifat risk averse. 
Selama kurun waktu 2012-2016 posisi RISK minimum ditempati oleh PT. Bara Jaya Internasional Tbk. (ATPK) dengan nilai sebesar 0,00625. PT. Bara Jaya Internasional Tbk. (ATPK) menempati posisi ini pada tahun 2013, hal ini menunjukkan bahwa perusahaan tersebut cenderung bersifat risk avers. Sedangkan dalam kurun waktu 2012-2016 posisi RISK maksimum ditempati oleh PT. Samindo Resources Tbk. (MYOH) dengan nilai sebesar 2719,15581. PT. Samindo Resources Tbk. (MYOH) menempati posisi ini pada tahun 2014, hal ini menunjukkan bahwa perusahaan tersebut cenderung bersifat riak taker. Nilai rata-rata (mean) dari karakter eksekutif sebesar 38,4636918 dan nilai

Selama kurun waktu 2012-2016 posisi SIZE minimum ditempati oleh PT. Elnusa Tbk. (ELSA) dengan nilai sebesar 15,24844. PT. Elnusa (ELSA) menempati posisi ini pada tahun 2016. Hal ini menunjukkan bahwa perusahaan terebut memiliki jumlah asset yang lebih kecil dibandingkan perusahaan lainnya. Sedangkanselama kurun waktu 2012-2016 nilai maksimum dimiliki oleh PT. Medco Energy Internasional Tbk. (MEDC) dengan nilai sebesar 31,14255. PT. Medco Energy Internasional Tbk. (MEDC) menempati posisi ini pada standar deviasi sebesar 322,68470147 . Dari tabel diatas dinyatakan bahwa nilai standar deviasi lebih besar dibandingkan nilai rata-rata (mean) yang berarti bahwa sebaran data karakter eksekutif bersifat heterogen, dikarenakan sebaran data bervariasi, yang berarti bahwa variabel karakter eksekutif mempunyai tingkat penyimpangan yang tinggi. Maka jika seorang pimpinan perusahaan dengan sifat risk taker akan cenderung untuk dapat menimbulkan resiko.

Ukuran Perusahaan dapat dihitung dengan cara mentransformasikan kedalam logaritma natural menurut Ghozali (2006). Sehingga dapat di rumuskan sebagai berikut: $S I Z E=L n$ Total Asset tahun 2014 karena memiliki jumlah asset yang besar. Nialai rata-rata (mean) dari size sebesar 25,1378352 dan nilai standar deviasi sebesar 4,6631926. Nilai standar deviasi lebih kecil dibandingkan dengan nilai ratarata (mean) yang berarti tingkat sebaran data size terbilang kecil dan bersifat homogen, yang berarti rata-rata ukuran perusahaan mempunyai tingkat penyimpangan yang rendah. Jika semakin besar perusahaan maka semakin detail pula hal-hal yang akan diungkapkan seperti tentang manajemen resiko perusahaan, karena 
perusahaan besar dianggap mampu untuk menyediakan informasi tersebut.

Perusahaan yang diaudit oleh KAP The Big Four memiliki tingkat kecurangan yang lebih rendah dibandingkan dengan perusahaan yang diaudit oleh KAP non The Big Four (Annisa dan kurniasih, 2012). Apabila perusahaan diaudit oleh KAP The Big Four maka mendapatkan nilai 1 dan 0 jika sebaliknya.

Nilai rata-rata (mean) dari kualitas audit adalah sebesar 0,66 sedangkan nilai standar deviasi sebesar 0,476 . Nilai standar deviasi lebih kecil atau dibawah rata-rata (mean) yang berarti sebaran data kualitas audit terbilang kecil dan bersifat homogen, yang berarti bahwa variabel kualitas audit mempunyai tingkat penyimpangan rendah. Maka jika dalam suatu perusahaan yang diaudit oleh KAP The Big Four akan terhindar dari tindakan tax avoidance. karena KAP The Big Four memiliki reputasi tinggi dan memiliki dorongan untuk menyediakan kualitas audit yang secara terus-menerus untuk mencegah hal-hal yang dapat merusak reputasi mereka.

Komite audit didefinisikan suatu komite yang bekerja secara professional dan independen yang dibantu oleh dewan komisaris dan dengan demikian tugasnya adalah membantu memperkuat fungsi dewan komisaris atau dewan pengawas dalam menjalankan fungsi pengawasan (oversight) atas proses pelaporan keuangan, manajemen resiko, pelaksanaan audit dan implementasi dari corporate governance di perusahaan-perusahaan. Komite audit dapat dihitung mengunakan rumus seperti berikut ini :

Audit $=\sum$ Anggota Komite Audit di Perusahaan

Variabel ini diuji untuk menghasilkan nilai minimum, maksimum, rata-rata (mean) dan standar deviasi.

Tabel 1

Statistik Deskriptif Variabel Penelitian

\begin{tabular}{lrrrr}
\hline Variabel penelitian & Minimum & Maksimum & Rata-rata & \multicolumn{1}{c}{$\begin{array}{l}\text { Deviasi } \\
\text { Standar }\end{array}$} \\
\hline Tax Avoidance & 0,01420 & 0,9027 & 0,398950 & 0,2009166 \\
Karakteristik & 0,00625 & 2719,1558 & 38,463692 & 322,6847015 \\
Eksekutif & & & & \\
Size & 15,24844 & 31,1426 & 25,13783 & 4,6631926 \\
Kualitas Audit & 0 & 1 & 0,66 & 0,476 \\
Komite Audit & 2 & 6 & 3,21 & 0,558 \\
\hline
\end{tabular}


Berdasarkan tabel 1 dapat diketahui bahwa selama kurun waktu 2012-2016 nilai minimum Komite Audit ditempati oleh PT. Baramulti Suksessarana Tbk (BSSR) dengan nilai sebesar 2. PT. Baramulti Suksessarana Tbk (BSSR) menempati posisi ini pada tahun Pada tahun 2014, hal ini menunjukkkan bahwa perusahaan tersebut memiliki jumlah komite audit yang sangat sedikit yakni 2 orang. Sedangkan selama kurun waktu 20122016 nilai maksimum Komite Audit ditempati oleh PT. Cita Mineral Investindo (CITA) Tbk. Dengan nilai sebesar 6. PT. Cita Mineral Investindo (CITA) Tbk. menempati posisi ini pada tahun 2012, yang berarti jumlah komite audit pada perusahaan tersebut yaitu 6 orang. Nilai rata-rata (mean) dari komite audit adalah sebesar 0,321. Nilai standar deviasi sebesar 0,558. Nilai standar deviasi lebih besar atau diatas nilai rata-rata yang berarti sebaran data komite audit bersifat heterogen,dikarenakan sebaran data yang bervariasi, yang berarti rata-rata variabel komite audit mempunyai tingkat penyimpangan yang tinggi. Sehingga dengan banyaknya jumlah komite audit dalam sebuah perusahaan pertambangan tidak mengurangi praktik tax avoidance.

Hasil dari hipotesis simultan (Uji F) dapat dilihat sebagai berikut :

Tabel 2

Hasil Uji Regresi

\begin{tabular}{lrr}
\hline \multicolumn{1}{c}{ Variabel Penelitian } & Nilai t & Signifikansi \\
\hline Konstanta & 1,430 & 0,157 \\
Karakteristik Eksekutif & $-0,956$ & 0,342 \\
Size & 0,797 & 0,428 \\
Kualitas Audit & 3,152 & 0,002 \\
Komite Audit & $-1,025$ & 0,309 \\
\hline Nilai F-test & & 2,790 \\
Signifikansi Nilai F-test & & 0,033 \\
Adj R & & 0,0933 \\
\hline
\end{tabular}

Sumber: Data yang diolah

Keterangan: Variabel Dependen: Tax Avoidance

Ukuran Perusahaan, Kualitas Audit dan

Berdasarkan tabel 2 dapat Komite Audit secara simultan diketahui bahwa nilai signifikansi berpengaruh terhadap tax avoidance sebesar 0,033. Nilai signifikansi atau $\mathrm{H}_{1}$

tersebut dibawah tingkat signifikansi

Berdasarkan tabel 2 diketahui sebesar 0,05 atau $0,033<0,05$. Hal ini bahwa nilai adjusted $\mathrm{R}$ square sebesar menunjukkan bahwa Kualitas Audit, 0,093. Hal ini menunjukkan bahwa 
sebesar 9,3 persen variabel independen yang terdiri dari karakter eksekutif, ukuran perusahaan, kualitas audit dan komite audit mampu menjelaskan variabel tax avoidance, sedangkan sisanya 90,7 persen dijelaskan oleh variabel lain diluar variabel independen yang diteliti. Selain itu nilai adjusted $\mathrm{R}$ square sebesar 0,093 memperlihatkan bahwa kemampuan variabel independen dalam menjelaskan variabel dependen rendah karena $\leq 50$ persen.

Pada tabel 2 dapat dicrmati bahwa nilai $\mathrm{t}$ untuk variabel independen kualitas audit 3,125 dengan signifikasi 0,002. Hasil tersebut dapat diinterpretasikan bahwa kualitas audit memiliki pengaruh positif terhadp Tax Avoidance. Semakin tinggi kualitas audit maka semakin tinggi kecenderungan untuk melakukan minimalisasi beban pajak dengan memanfaatkan tax avoidance.

Karakter Eksekutif dengan nilai t sebesar -956 dan nilai signifikansi 0,342 . Nilai signifikasi untuk variabel karakter eksekutif menunjukkan nilai diatas tingkat signifikasi sebesar 0,05 sehingga dapat disimpulkan bahwa karakter eksekutif tidak berpengaruh terhadap tax avoidance.

Hasil pengujian terhadap pengaruh ukuran perusahaan terhadap tax avoidance berdasarkan tabel 2 diketahui nilai t sebesar 0,797 dengan nilai signifikasi 0,428 lebih besar dari 0,05 Sehingga dapat disimpulkan bahwa ukuran perusahaan tidak berpengaruh terhadap tax avoidance.

Pengujian hipotesis keempat dilakukan untuk menguji pengaruh komite audit terhadap tax avoidance. berdasarkan tabel 2 diketahui nilai $t$ sebesar -1,025 dengan nilai signifikasi 0,309 lebih besar dari 0,05. Sehingga dapat disimpulkan bahwa komite audit tidak berpengaruh terhadap tax avoidance.

\section{SIMPULAN DAN \\ KETERBATASAN}

\section{Simpulan}

Berdasarkan hasil analisis dan pembahasan yang telah dijelaskan pada bab sebelumnya, maka dapat disimpulkan sebagai berikut :

1. Variabel Karakter Eksekutif, Ukuran Perusahaan, Kualitas Audit dan Komite Audit secara simultan mempunyai pengaruh signifikan terhadap Tax Avoidance pada perusahaan pertambangan yang terdaftar di Bursa Efek Indonesia periode 2012-2016,

2. Variabel Karakter Eksekutif secara parsial tidak berpengaruh 
berpengaruh terhadap tax

avoidance. Apabila eksekutif semakin bersifat risk averse maka akan semakin kecil tindakan tax avoidance yang dilakukan. Hasil dari penelitian ini tidak sesuai dengan hipotesis yang dikemukakan dalam penelitian ini.

3. Variabel Ukuran perusahaan secara parsial tidak berpengaruh terhadap tax avoidance, Artinya bahwa ukuran perusahaan dengan jumlah asset yang semakin besar maka akan semakin besar pula modal yang ditanam dan semakin besar pula perputaran dana dalam perusahaan yang dikelola sehingga dapat mampu meningkatkan kinerja perusahaan, namun belum tentu meningkatkan tax avoidance pada perusahaan, dalam penelitian(Melawati, Nurlaela \& Wahyuningsih, 2016). Hasil dari penelitian ini tidak sesuai dengan hipotesis yang dikemukakan dalam penelitian ini.

4. Variabel Kualitas audit secara parsial berpengaruh terhadap tax avoidance. Sehingga perusahaan yang diaudit oleh KAP the big four pada perusahaan pertambangan dapat mengurangi tindakan tax avoidance dalam perusahaan. Hasil dari penelitian ini sesuai dengan hipotesis yang dekemukakan dalam penelitian ini.

5. Variabel Komite audit secara parsial tidak berpengaruh terhadap tax avoidance, Sehingga adanya komite dalam sebuah perusahaan pertambangan tidak mengurangi praktik tax avoidance. Hasil dari penelitian ini tidak sesuai dengan hipotesis yang dikemukakan dalam penelitian ini.

\section{Keterbatasan dan Saran}

Hasil penelitian ini menunjukan bahwa diantara variabel independen yang diteliti hanya variabel Kualitas Audit yang berpengaruh terhadap Tax Avoidance. Dari penelitian-penelitian sebelumnya, tanpa membedakan objek penelitian apakah perusahaan manufaktur atau perusahaan pertambangan juga menghasilkan kesimpulan yang sama. Berdasar hal tersebut akan sangat berguna jika penelitian selanjutnya berhasil menemukan variabel lain yang berpengaruh terhadap Tax Avoidance sehingga dapat lebih jelas mengungkap 
alasan lain perusahaan melakukan Tax

Avoidance selain Kualitas Audit.

Penting pula bagi Pemerintah untuk memperketat pengawasan terhadap perusahaan-perusahaan melalui regulasi fiskal, intensifikasi dan ekstensifikasi pajak agar dapat meningkatkan penerimaan Negara dari sektor pajak serta menyelamatkan uang Negara dari rongrongan pihak yang tidak bertanggungjawab yang melakukan Tax Avoidance.

\section{DAFTAR PUSTAKA}

Alviani, Khoirunisa.2016. Pengaruh Corporate Governance, Karakter Eksekutif, Ukuran Perusahaan, Dan Leverage Terhadap Penghindaran Pajak (Tax Avoidance). JOM Fekon Vol. 3. No. 1

Annisa N., and Kurniasih L., 2012, Pengaruh Corporate Governance terhadap Tax Avoidance, Jurnal Akuntansi dan Auditing, Vol. 8, No. 2, 123136.

BAPEPAM.2012. Salinan Keputusan Ketua Badan Pengawas Pasar Modal dan Lembaga Keuangan, Nomor : kep-431/b1/21012 tentang kewajiban penyampaian laporan tahunan bagi emiten atau perusahaan publik. Jakarta.

Budiman, J., dan Setiyono.2012. Pengaruh Karakter Eksekutif terhadap Penghindaran Pajak (Tax Avoidance). Skripsi, Universitas Islam Sultan Agung.

Budiman, J. \& Setiyono. 2013. Pengaruh Karakter Eksekutif terhadap Penghindaran Pajak (Tax Avoidance). prosiding.
Simposium Nasional Akuntansi XV.

Butje, Stella \& Tjondro Elisa. 2014. Pengaruh Karakter Eksekutif Dan Koneksi Politik Terhadap Tax Avoidance. Tax \& Accounting Review, Vol 4, No 2. Dewi, Ni Nyoman Kristiana dan Jati I Ketut. 2014. Pengaruh Karakter Eksekutif, Karakteristik Perusahaan, Dan Dimensi Tata Kelola Perusahaan Yang Baik Pada Tax Avoidance di Bursa Efek Indonesia. E-Jurnal Akuntansi Universitas Udayana $6.2: 249-260$.

Dyreng. S.D., Hanlpn, M, \& Maydew, EL. 2010. The Effects of Executives on Corporate Tax Avoidance. The Accounting Review, 85 (4) : 1163-1189.

Fadhilah, Rahmi. 2014. Pengaruh Good Governance Terhadap Tax Avoidance (Studi Empiris Pada Perusahaan Manufaktur Yang Terdaftar di BEI tahun 20092011). E-jurnal Universitas Negeri Padang.

Hardelia, Medisa. 2015. "Pengaruh Karakteristik Perusahaan dan Reformasi Perpajakan Terhadap Penghindaran Pajak (Tax Avoidance) Pada Perusahaan LQ-45 yang Terdaftar di Bursa Efek Indonesia”. Skripsi, Fakultas Ekonomi Universitas Riau.

Hormati, Asrudin, 2009, Karakteristik Perusahaan Terhadap Kualitas Implementasi Corporate Governance, Jurnal Keuangan dan Perbankan, Vol. 13 no. 2 ; 288-298

Husnan, Suad dan Enny Pudjiastuti.2012. Dasar-dasar Manajemen Keuangan. Edisi Keenam, Cetakan Pertama, UPP STIM YKPN, Yogyakarta. 
Hutagaol, J. 2007. Perpajakan : Isu-isu Kontemporer. Yogyakarta ; Graha Ilmu.

Imam, Ghazali. 2016. Aplikasi Analisis Multivariate Dengan Program IBM SPSS 23. Semarang: Badan Penerbit Universitas Diponegoro.

Kanagaretnam, Kiridaran; LEE, Kiat Bee Jimmy; Chee Yeow LIM; and Lobo, Gerald J..2016. “ Relation between auditor quality andcorporate tax aggressiveness: Implication of cross-country institutional differences." Auditing : A Journal of Practice and Theory. 35, (4), 105-135. Research Collection School Of Accountancy.

Kurniasih, Tommy dan Sari Maria M. Ratna . 2013. Pengaruh Return On Assets, Leverage, Corporate Governance, Ukuran Perusahaan, dan Kompensasi Rugi Fiskal pada Tax Avoidance.Buletin Studi Ekonomi Vol 18, No.1, Halaman 58-65.

Kusuma, Hendra. 2017. Sudah 9 tahun Setoran Pajak RI Tak Pernah capai Target. Retrieved from https:/finance.detik.com/beritaekonomi-bisnis/d-3728111

Lewellen, K. 2006. Financing decisions when managers are risk averse. Journal of financial economics 82 (3): 551-89.

Maharani I. G. A. C., dan Suarnana, K. A., 2016. "Pengaruh dari proporsi komisaris independen, komite audit, preferansi risiko neksekutif, dan ukuran perusahaan pada penghindaran pajak perusahaan manufaktur".

Mangoting, Yenni. 1999. Tax Planning : Sebuah Pengantar Sebagai Alternatif Meminimalkan Pajak. Jurnal Akuntansi dan Keuangan, Vol. 1, No. 1, Mei 1999, hal 4353.
Membunuh Indonesia, 2017, Kejahatan Keuangan di sektor Pertambangan, 20 Januari 2019

Merdeka.Com, 2017, Analisa Faisal Basri soal target pajak jarang tercapai. Retrieved from https/www.google.com/amp/m. merdeka.com

Nuralifmida Ayu Annisa dan Lulus Kurniasih. " Pengaruh Good Corporate Governance dan Ukuran Perusahaan terhadap Tax Avoidance". Jurnal Akuntansi \& Auditing Volume 8 No. 2/ Mei 2012 : Pp 95-189.

Nota Keuangan dan Anggaran Pendapatan Belanja Negara Perubahan Tahun Anggaran 2014 Republik Indonesia. Diunduh 30 Desember 2015.

Prasetyo, 2017, Pengaruh Likuiditas,Leverage,

Profitabilitas, Komisaris Independen, Dan Ukuran Perusahaan Terhadap Agresivitas Pajak, Skripsi, Surakarta; IAIN Surakarta

Prebble, Z. M., \& Prebble, J. (2010). The Morality Of Tax Avoidance.

Rachmithasari, Annisa Fadilla. 2015. "Pengaruh Return On Assets, Leverage, Corporate Governance, Ukuran Perusahaan dan Kompensasi Rugi Fiskal Pada Tax Avoidance". Skripsi. Program Sarjana (S1) Universitas Muhammadiyah Surakarta. Surakarta.

Saputra, M. F., Rifa Dandes., Rahmawati Novia. 2015. Pengaruh Corporate Governance, Profitabilitas Dan Karakter Eksekutif Terhadap Tax Avoidance Pada Perusahaan Yang Terdaftar Di BEI. JAAI VOLUME 19. NO.1

Surbakti, Theresa Adelina Victoria. 2012. "Pengaruh Karakteristik Perusahaan dan Reformasi 
Perpajakan Terhadap

Penghindaran Pajak di

Perusahaan Industri Manufaktur yang Terdaftar di Bursa Efek Indonesia Tahun 2008-2010". Skipsi Jurusan Akuntansi Fakultas Ekonomi Universitas Indonesia, Jakarta.

Swingly, Calvin dan Sukarta I Made. 2015. Pengaruh Karakter Eksekutif, Komite Audit, Ukuran Perusahaan, Leverage Dan Sales Growth Pada Tax Avoidance. EJurnal Akuntansi Universitas Udayana $10.1:$ 47-62.

Winata, Fenny. 2014. Pengaruh Corporate Governance Terhadap Tax Avoidance Pada Perusahaan yang terdaftar di BEI tahun 2013. Tax \& Accounting Review, VOL. 4, NO.1,2014.

Xu, Shawn dan Zheng, Kenneth.2016. "Tax Avoidance and Asymetric Cost Behavior".

Zain, Mohammad. 2008. Manajemen Perpajakan ed.3. Jakarta : Salemba Empat. 